\title{
Estimating the suspended sediment yield in a river network by means of geomorphic parameters and regression relationships
}

\author{
S. Grauso ${ }^{1}$, G. Fattoruso ${ }^{2}$, C. Crocetti ${ }^{3}$, and A. Montanari ${ }^{3}$ \\ ${ }^{1}$ Dipartimento Ambiente, Cambiamenti Globali e Sviluppo Sostenibile, ENEA Centro Ricerche Casaccia, Roma, Italy \\ ${ }^{2}$ Dipartimento Ambiente, Cambiamenti Globali e Sviluppo Sostenibile, ENEA Centro Ricerche Portici (Napoli), Italy \\ ${ }^{3}$ Faculty of Engineering, University of Bologna, Italy
}

Received: 16 March 2007 - Published in Hydrol. Earth Syst. Sci. Discuss.: 23 March 2007

Revised: 30 October 2007 - Accepted: 3 January 2008 - Published: 31 January 2008

\begin{abstract}
An application of regression relationships depending on geomorphic parameters is proposed to predict the amount of the average annual suspended sediment yield at different sections of the drainage network. Simple and multiple regression relationships, utilising the drainage density and the hierarchical anomaly index as independent variables, based on data from 20 river basins of different size located in Italy, are here tested. An application is also shown for a small river basin located in central Italy where it is possible to compare the obtained suspended sediment yield estimates with reservoirs siltation data. The results confirm the potential applicability of regression equations for estimating the suspended sediment yield depending on the topological behaviours of the river network. A discussion of the reliability of the method for ungauged basins is also provided, which puts in light the necessity of additional tests to support the application of the approach to small size watersheds.
\end{abstract}

\section{Introduction}

The assessment of sediment yield is an important issue in engineering practice. The transport of sediments in rivers implies a series of side effects such as reservoirs siltation and channel bed modification which can interfere with human activities. In particular, sediments eroded from the slopes can accumulate in the river network therefore affecting channel water conveyance. This is the case, for example, of the watersheds comprised between the Apennine ridge and the Adriatic Sea in central Italy, where streams are relatively short and the river network morphology is characterised by very steep slopes and gently inclined valley bottoms. Being able to quantify the potential sediment yield along a watercourse is therefore an important requirement in land and river man-

Correspondence to: S. Grauso

(grauso@ casaccia.enea.it) agement. In Italy, observations of suspended sediment yield are usually present only at the outlet of large watersheds. Therefore there is a lack of information with regard to the sediment supply and deposition processes along the river network, especially in the case of small watersheds.

In order to estimate the potential sediment yield in ungauged river networks researchers have tried, for many years, to develop empirical, such as the Modified Universal Soil Loss Equation (Williams, 1975) and physically based, such as SHESED (Wicks and Bathurst, 1996), approaches. Both approaches try to parameterise the sediment detachment and transport processes on the basis of different variables. To this aim, Kirkby and Cox (1995) pointed out that hydrological processes responsible for rill formation seem to be prominent at the hillslope scale. Topographic and pedologic behaviours, as well as vegetation, prevail at the basin scale, which represents a local planning level; while climate and lithology take relevance at the regional scale, which constitute the national and international level.

The estimation model should be chosen by taking into account watershed behaviours and data availability. In fact, physically based models are expected to provide a detailed schematisation of the inherent processes but require the integration of various submodels dealing with meteorology, hydrology and hydraulics. Such models may be extremely onerous in term of input data requirements. As a matter of fact, the high number of the involved parameters may lead to significant uncertainty of the soil erosion estimates when the input information is scarce.

To overcome this problem, several authors have shown the effectiveness of statistical relationships which allow one to estimate the river sediment transport depending on easily available geomorphologic, hydrological and climatic parameters. In this respect, Anderson (1957) considered the use of multiple regression analysis to relate sediment yield to watershed behaviours, while Langbein and Schumm (1958) studied the link between mean annual precipitation and sediment

Published by Copernicus Publications on behalf of the European Geosciences Union. 
yield in drainage basins in the United States. Fournier (1960) developed an empirical equation to predict suspended sediment yield depending on watershed morphology and climate. In detail, the independent variables of the relationship developed by Fournier (1960) are the relief index $\mathrm{H}^{2} / S$, where $H$ is the mean altitude of the basin and $S$ is the basin area, and a climatic index given by the ratio $p^{2} / P$, where $p$ is the mean maximum monthly precipitation $(\mathrm{mm})$ and $P$ is the average yearly rainfall $(\mathrm{mm})$. Douglas (1968) set up a multiple regression equation for small watersheds located in Australia to express the sediment yield depending on three parameters, namely, the Fournier's climatic index previously introduced, the bifurcation ratio and the drainage density $D_{d}$, defined as the ratio between the total stream channels length and the basin area (Horton, 1945). Lately, Ichim and Radoane (1987) analysed 99 small Romanian catchments to develop multiple regression models for sediment yield estimation. Recently Restrepoa et al. (2006) developed a multiple regression model for estimating the sediment yield in a South American watershed.

In Italy similar investigations were carried out by Gazzolo and Bassi $(1961,1964)$ and by Cavazza $(1962,1972)$. Lately, Ciccacci et al. $(1977,1980,1987)$ investigated the correlation between the average yearly sediment yield per unit watershed area (SSY) and some geomorphologic, hydrological and climatic parameters from 20 watersheds in Italy. They found a significant dependence between SSY and the drainage density. Moreover, in order to provide a better explanation of SSY variability, they also performed a multiple regression analysis by including a second variable which, in turn, was the hierarchical anomaly index $\Delta_{a}$, which depends on the degree of river network organisation in a binary tree shaped structure (Avena et al., 1967), the mean annual river discharge $Q\left(\mathrm{~m}^{3} / \mathrm{s}\right)$ and Fournier's climatic index.

From a mechanistic point of view, the dependence between the yearly sediment yield and the above geomorphoclimatic parameters is explained by the relationships between climate, watershed features and river network topology. In fact, watershed erosion is favoured by scarce vegetation coverage, bedrock and soil erodibility and intense weather events.

Eroded sediments are subsequently conveyed to the river network. Part of them can be deposited along the stream bed and the remaining part is conveyed downstream as sediment yield. By comparing the estimated value of the SSY for subsequent river cross sections along the main stream one can obtain an estimate of the amount of the deposited sediments.

On the basis of the above considerations, the aim of this study is to further prove the reliability of the geomorphic approach for estimating the SSY at different cross-sections of a drainage basin depending on selected geomorphologic features of the contributing watersheds. A systematic testing of the relationships previously proposed by Ciccacci et al. (1987) is first presented in order to verify their reliability for ungauged basins. Then, we show an application of the lat- ter to the Calvano River basin, located in central Italy, where the availability of reservoir siltation data allows to check the reliability of the SSY estimates for a number of small size subwatersheds.

The final aim is to derive a working methodology suitable for our purposes, in order to provide land managers with a technically and scientifically relevant insight into the order of magnitude of the sediment yield and sediment deposition along the river network. The empirical nature of the adopted approach is similar to that of the Universal Soil Loss Equation and derived formulations (Wischmeier and Smith, 1965, 1978; Williams, 1975; Renard et al., 1997).

\section{Case studies description}

\subsection{The 20 gauged Italian watersheds}

As already mentioned in the introduction, a regression analysis has been performed by Ciccacci et al. (1987) for the purpose of estimating SSY at the outlet of 20 watersheds located along the Italian peninsula, from north to south of the Apennine mountain ridge. In the selected watersheds, the climate is varying from fresh-temperate, in the hilly-mountainous zones with average yearly precipitations more than $1 \mathrm{~mm}$, to more typically Mediterranean, i.e. hot-subtropical temperate, in the hilly-coastal zones with average yearly rainfall around $600-700 \mathrm{~mm}$. Mean annual water discharge also varies from less than $1 \mathrm{~m}^{3} \mathrm{~s}^{-1}$ in the smallest watersheds $\left(<100 \mathrm{~km}^{2}\right)$ which are located in the southern Apennine, to $3-13 \mathrm{~m}^{3} \mathrm{~s}^{-1}$ in the medium size watersheds $(100$ $600 \mathrm{~km}^{2}$ ) of the northern-central Apennines; the maximum value $\left(32 \mathrm{~m}^{3} \mathrm{~s}^{-1}\right)$ is showed by the Volturno river basin, located in the southern Apennines, which is the widest one $\left(2.015 \mathrm{~km}^{2}\right)$. For the most part they are composed of terrigenous rocks such as marly arenaceous flysch, clays, sandy clays and conglomerates. It is generally agreed that suspended sediment may represent as much as $90 \%$ of total sediment yield in morphoclimatic areas ranging from arid to humid, if terrigenous rocks are prevalent (Cooke and Doornkamp, 1974).

The list of the watersheds along with the value of their drainage density, hierarchical anomaly index and contributing area are reported in Table 1.

\subsection{The Calvano River ungauged watershed}

The Calvano watershed, whose contributing area at the basin outlet is about $35 \mathrm{~km}^{2}$, is located in central Italy close to the Adriatic sea (Fig. 1). The maximum elevation is $461 \mathrm{~m}$ a.s.l., at the south-western edge of the area. The landscape is characterised by hilly ridges and narrow stream valleys, mainly oriented SW-NE, modelled on sandy-clay terrains and subject to significant erosive processes. These lands are made up by pelagic sediments and continental eroded materials of 

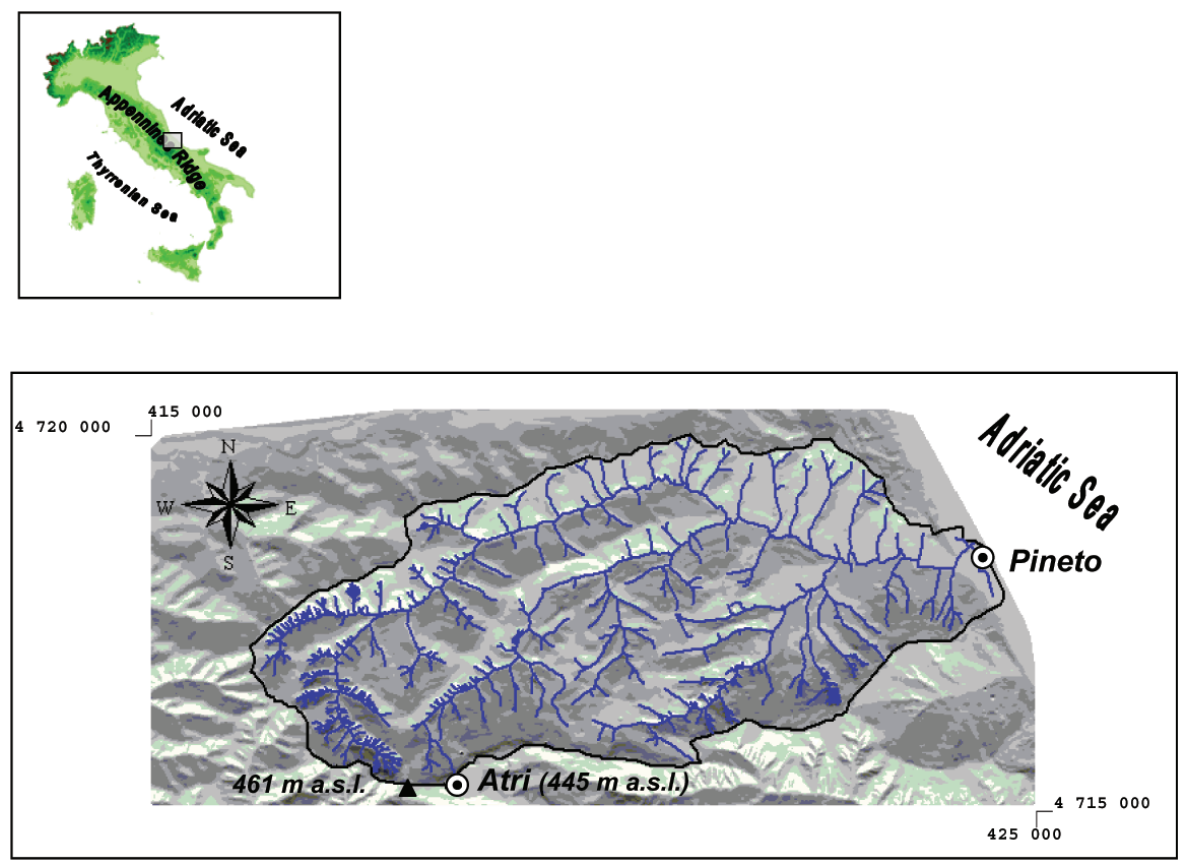

Fig. 1. Geographic location of the Calvano watershed. Projection East U.T.M. 33 European Datum 1950.

middle Pliocene-lower Pleistocene age (the Mutignano Formation). The hilltops are constituted by sands and conglomerates of marine-transitional and continental environments and capping clays with intercalated conglomerates and sands ("Blue Clays", Fig. 2). Recent alluvial deposits and fluvial terraces (Holocene) are displaced along the valley bottoms.

The climate over the watershed is Mediterranean, with long dry summers and rainfalls concentrated in winter periods. The average yearly rainfall is about $750 \mathrm{~mm}$. The climatic regime induces soil aridity and superficial soil cracks during the summer, mainly on clay south facing slopes, which heavily affect slope stability and soil erosion vulnerability. The soil is characterised by a reduced permeability that may induce flash floods after heavy rainstorms.

Land use is characterised by intense urbanisation along the coast and by scattered farms in the inner hilly areas, which are extensively cultivated with arables, olives and vineyards. The frequent use of cultivation techniques such as up and down tillage triggers rill/gully erosion and mudflow processes that, in turns, can generate severe erosion forms such as large mass movements and badlands on sandy-clay slopes. Nowadays, many cultivated areas are being abandoned and the natural vegetation is beginning to reinstate. Some small reservoirs are spread over the watershed for irrigation purposes.

According to Strahler's classification, the Calvano River basin is ranked as 5 th order. It shows a sub dendritic drainage network pattern, where the main stream is controlled by recent tectonic activity while secondary streams are strongly influenced by lithology and slope dynamics. In fact, the hy-
Table 1. Drainage density $\left(D_{d}\right)$, hierarchical anomaly index $\left(\Delta_{a}\right)$ and contributing area (A) for the watersheds considered by Ciccacci et al. (1987).

\begin{tabular}{lccc}
\hline Watershed & $\begin{array}{c}D_{d} \\
\mathrm{~km}^{-1}\end{array}$ & $\Delta_{a}$ & $\begin{array}{c}\mathrm{A} \\
\mathrm{km}^{2}\end{array}$ \\
\hline Trebbia & 0.23 & 0.08 & 226 \\
Enza & 0.25 & 0.05 & 670 \\
Idice & 0.25 & 0.06 & 397 \\
Senio & 0.18 & 0.06 & 269 \\
Foglia & 0.24 & 0.07 & 603 \\
Orcia & 0.22 & 0.07 & 580 \\
Tavo & 0.13 & 0.07 & 109 \\
Volturno & 0.16 & 0.08 & 2015 \\
C. S. Maria & 0.10 & 0.05 & 60 \\
Triolo & 0.13 & 0.06 & 54 \\
Casanova & 0.13 & 0.03 & 52 \\
Salsola & 0.13 & 0.05 & 43 \\
Vulgano & 0.11 & 0.07 & 94 \\
Celone & 0.14 & 0.05 & 86 \\
Venosa & 0.14 & 0.05 & 261 \\
Atella & 0.17 & 0.05 & 158 \\
Agri (Grumento) & 0.11 & 0.04 & 278 \\
Agri (Tarangelo) & 0.13 & 0.04 & 507 \\
Delia & 0.12 & 0.04 & 140 \\
Gornalunga & 0.19 & 0.05 & 232 \\
\hline Range & $2.21-5.62$ & $0.36-1.62$ & $43-2015$ \\
\hline
\end{tabular}




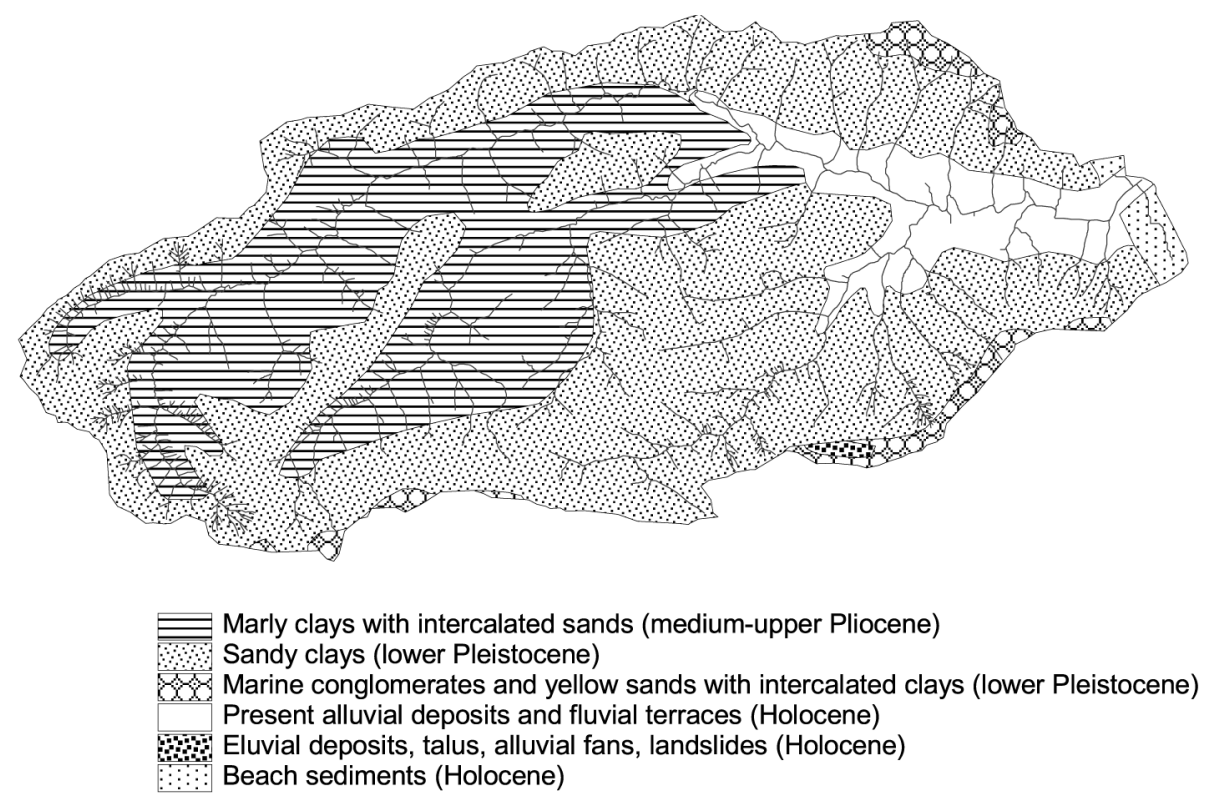

Fig. 2. Geolithological scheme.

drographic network is mostly developed in the hilly part of the watershed, where well developed, sometimes spectacular, badlands systems (calanchi) occur, prevailingly on south facing slopes. Both the main and the tributary watercourses are embedded in narrow valleys. The Calvano main stream valley opens in the coastal-alluvial plain which is rather limited in extensions as it is a few kilometres long from the confluence of the two main tributaries (Fosso Reilla and Fosso di Casoli) to the sea mouth.

The above described geomorphological setting determines a significant risk of flooding for the human settlements located downvalley (CNR, 1993), mainly around the city of Pineto which is located on the river mouth. In July 1999 a severe flood occurred that submerged the coastal area with heavy damages to structures, roads, buildings and a high number of evacuees. Immediately after that catastrophic event, the local Authority commissioned a study with the aim to design precautionary measures and river engineering works to reduce the flood risk. The triggering factor of the flood that occurred in 1999 was recognised as the accumulation along the main stream of the Calvano River of sediments supplied from the tributaries. The sediment yield was favoured by the low bedrock permeability, the high watershed slope and the fine texture of sediments (Commissione Tecnica, 1999).

\section{Framework of the analysis}

The SSY is herein estimated by using the geomorphic approach, depending on selected geomorphological features of the contributing watershed. For the Calvano watershed the aim is to obtain a distributed picture of the concentration of suspended sediments along the river network, therefore identifying the river reaches where sediment income and deposition mainly occur.

The basic assumption of the method is that the SSY can be reliably predicted depending on the drainage density $D_{d}$ and the hierarchical anomaly index $\Delta_{a}$ of the river network, through a multiple regression approach that is calibrated by using an extended data set of SSY data collected in the 20 Italian river basins described in Sect. 2.1. We will identify with $G_{a}$ the minimum number of 1 st order streams necessary to make a drainage network perfectly ordered in a tree shaped structure with streams of order $u$ flowing into streams of order $u+1$. Then, the hierarchical anomaly index $\Delta_{a}$ is given by the ratio $G_{a} / N_{1}$ (Avena et al., 1967), where $N_{1}$ the number of 1 st order channels actually occurring in the drainage network.

$D_{d}$ and $\Delta_{a}$ appear to be significant parameters when estimating SSY, as they can synthesise the links among climatic, vegetation, river network and geological conditions whose combination results in watershed erodibility potential. From a mechanistic point of view, the connection among SSY, $D_{d}$ and $\Delta_{a}$ can be explained by qualitative considerations. In fact, as soil erosion leads to the development of the drainage network, drainage density and SSY should be related by a non decreasing relationship. Further insights can be gained by considering that the drainage density of a watershed is a conservative function of the drainage densities of its subwatersheds and therefore it is conserved through an increase of the catchment extension. Given that sediment deposition along the river network is inducing a dispersion of the sedi- 
ments themselves, it follows that the link between SSY and drainage density should be non conservative with respect to an increase of watershed area. Therefore, if sediment deposition occurs, SSY and $D_{d}$ should be non linearly related. More specifically, under the assumptions that drainage density decreases for increasing watershed area (because the average slope of the watershed decreases as well) SSY should decrease more than linearly for decreasing drainage densities.

An analogous reasoning may allow one to conclude that SSY should increase for increasing $\Delta_{a}$. In fact, a hierarchically anomalous river network implies that some streams flow into river reaches whose order is more than one unit greater. This induces an increase of SSY with respect to a perfectly ordered river network, given that the presence of anomalies typically indicates that the network is still under development and therefore the watershed is still undergoing a significant soil erosion. However, the structural form of the link between SSY and $\Delta_{a}$ is not easily identifiable with a qualitative analysis.

The recognition of the above links makes it reasonable to assume that a part of the variability of the SSY along the river network can be explained depending on $D_{d}$ and $\Delta_{a}$, with a non linear relationship with respect to the former.

3.1 Estimating the suspended sediment yield through regression relationships

Ciccacci et al. (1987) developed an extensive analysis of SSY data that refer to the 20 Italian watersheds described in Sect. 2.1. They found a significant dependence among SSY, $D_{d}$ and $\Delta_{a}$ that is expressed through the following regression equations:

$\mathrm{SSY}=10^{0.33 D_{d}+0.10 \Delta_{a}+1.45}$

$\mathrm{SSY}=10^{0.34 D_{d}+1.52}$

where SSY is expressed in $\mathrm{Mg} \mathrm{km}^{-2}$ year $^{-1}$ and $D_{d}$ in $\mathrm{km}^{-1}$. Equation (2), whose independent variable is $D_{d}$ only, can be applied when $\Delta_{a}$ is equal to zero, situation that occurs in catchments only consisting of 1 st order and 2 nd order streams. In these conditions, hierarchic anomaly parameters have no significance, considering that anomaly arises when some streams flow into river reaches whose order is more than one unit higher. The independent variables $D_{d}$ and $\Delta_{a}$ for Eqs. (1) and (2) above were estimated by analysing the drainage networks and basins contours mapped by using the 1:25000 official topographic maps of the Italian Military Geographic Institute (IGMI).

In a previous work, Ciccacci et al. (1980) observed that the exponential relationships above do not provide a good fit for high $D_{d}$. Accordingly, they proposed to apply a bilogaritmic relationships when $D_{d}$ exceeds a threshold value. However, in the present study the bilogaritmic approach was not considered because of the lack of an extended experimental data base that would be needed to perform a meaningful validation of its results. Therefore Eqs. (1) and (2) were herein applied only to basins where $D_{d}<7 \mathrm{~km}^{-1}$ (with only one exception. See Sect. 4 for more details).

The form of relationships (1) and (2) agrees with the mechanistic nature of the processes leading to SSY formation, in compliance with the qualitative considerations summarised above. Quantitative considerations to support the capability of the equations to reliably estimate SSY are provided here below.

\subsection{Validation of the regression relationships}

Ciccacci et al. (1987) reported a coefficient of determination for Eqs. (1) and (2) ranging from 0.95 to 0.96 and an average percentage error of $14 \%$. These statistics refer to the calibration mode and therefore provide limited information about the SSY estimates reliability in out of sample situations. Therefore some considerations and further analysis are needed to substantiate the effectiveness of the above equations when applied to ungauged basins. In fact, it is well known that regression approaches, as well as any empirical parametric model calibrated by fitting observed data, may experience a decrease of performance when applied in practice.

In order to inspect the capability of the proposed relationships to effectively predict the SSY in real world applications a validation exercise was herein performed by applying a jack-knife technique (Haan, 1977). The main features of the validation procedure can be summarised as follows:

1. the attention is focused on the 20 watersheds where SSY, $D_{d}$ and $\Delta_{a}$ data are available;

2. one of these watersheds, say watershed s, is removed from the set;

3. the regression equations are recalibrated by considering the SSY data and geomorphic characteristics of the 19 remaining watersheds;

4. using the regression equations identified at step 3 above the SSY for watershed s is estimated;

5. steps $2-4$ are repeated 19 times, each time with one of the remaining watersheds.

The 20 SSY estimates resulting from the model validation, hereafter referred to as jack-knifed SSY values, are then compared with the corresponding observed SSY. The comparison allows us to draw indications on the robustness and reliability of Eqs. (1) and (2).

Figure 3 shows a scatterplot of observed versus jackknifed SSY values. The coefficient of determination of observed versus simulated data in validation mode is equal to 0.98. The ANOVA test provided a regression F-significance $<0.001$ and a root mean square error 


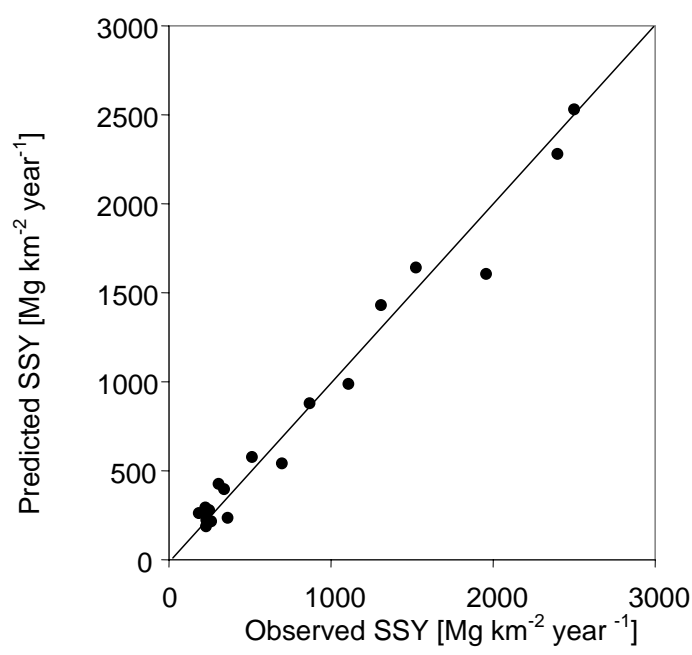

Fig. 3. Scatterplot of observed versus jack-knifed SSY values of the 20 Italian river basins studied by Ciccacci et al. (1987).

RMSE $=97.6 \mathrm{Mg} \mathrm{km}^{-2}$ year $^{-1}$. The sample of errors that affected the SSY estimates has a mean value that is not significantly different from 0 and a standard deviation equal to $116.38 \mathrm{Mg} \mathrm{km}^{-2}$ year $^{-1}$. Such errors look homoscedastic with respect to the value of the SSY estimates (see Fig. 3) and the hypothesis of Gaussianity could not be rejected at the 95\% confidence level accordingly to the Anderson-Darling and Kolmogorov-Smirnov normality tests (Kottegoda and Rosso, 1997). The above statistics could allow one to easily derive confidence bands for the obtained SSY estimates in real world applications. However, we believe that the sample of estimation errors is too short to allow a reliable uncertainty assessment. Nevertheless, it is evident that the performances of the proposed approach are satisfying for the purpose of obtaining a technically useful estimation of the suspended sediment yield along the river network.

\subsection{Application of the regression relationships to ungauged watersheds}

A first prerequisite for applying Eqs. (1) and (2) to ungauged catchments is to estimate $D_{d}$ and $\Delta_{a}$ by using topographic information with the same level of detail. Moreover, one should note that a decrease of the validation performances might be experienced if one applied Eqs. (1) and (2) to watersheds that are not similar with respect to the ones that were considered in the jack-knife validation procedure. From a practical point of view, it is first of all necessary to check that the values of $D_{d}$ and $\Delta_{a}$ of the considered watershed do not lie far too outside the range of the corresponding values of the calibration/validation data set. Table 1 shows the $D_{d}$ and $\Delta_{a}$ values of the watersheds considered by Ciccacci et al. (1987), which were used to perform the validation above. The range of the tested $D_{d}$ and $\Delta_{a}$ values is also given in or- der to provide technical indications about the applicability of the SSY estimation model. The homoscedasticity of the estimation error with respect to the value of the SSY estimates (see Fig. 3) is a significant indication that the reliability of these latter should not abruptly decrease if $D_{d}$ and $\Delta_{a}$ assume values that are slightly outside the ranges provided in Table 1. However, it is not advisable to sizeably extrapolate the regression equations.

Even if $D_{d}$ and $\Delta_{a}$ are compatible with the ranges spanned by the calibration data set, one should take into account that the validity of the method was checked with respect to a relatively limited set of climatic, geologic and hydrologic conditions and a relatively limited range of watershed extensions (see Table 1). Therefore, any practical application should be preceded by a careful evaluation of the physical behaviours of the considered watershed, that should not be dissimilar with respect to those considered by Ciccacci et al. (1987). The main characteristics of these latter are given in Sect. 2.1. Further details can be obtained in Ciccacci et al. (1987).

Moreover, one should note that the proposed relationships provide an assessment of the annual average SSY. They are not conceived to provide an estimate of the SSY that may occur during a short time span when local events, like landslides, may provide a significant contribution to SSY. Given that Eqs. (1) and (2) predict the SSY depending on $D_{d}$ and $\Delta_{a}$, they are suited for case studies where the main contribution to SSY comes from distributed soil erosion. This is the case of the 20 watersheds considered by Ciccacci et al. (1987) as well as the Calvano watershed. It follows that the role of spatially concentrated soil erosion should be carefully considered and separately evaluated.

It is worth mentioning that the correlation between the SSY and the drainage density has proven to be not as significant in some cases (Grauso et al., 2007). For example, Cannarozzo and Ferro $(1985,1988)$ found drainage density to be poorly significant in predicting SSY for a number of watersheds located in Sicily (southern Italy). This outcome was attributed mainly to the climatic characteristics of the considered Sicilian basins, where the hydrological regime is characterised by highly variable discharges during the year, due to extended droughts in the summer followed by severe storms occurring in autumn and winter. This behaviour induces the presence of relevant soil erosion in autumn which is not correlated with the river discharge and therefore is poorly related to the behaviours of the river network (Grauso et al., 2007).

Finally, it is worth mentioning that the above regression method for SSY estimation has been applied in several other studies in Italy (Ceci et al., 1998; Ciccacci et al., 1988; Battista et al., 1988; Lupia Palmieri et al., 1995; Agnesi et al., 1996; Massaro et al., 1996). In detail, Ceci et al. (1998) applied Eqs. (1) and (2) to an ungauged subcatchment of the Tavo River, which is located close to the Calvano basin and has similar climatic and geomorphological features. The Tavo River watershed is one of the 20 basins considered 
by Ciccacci et al. (1988). The SSY estimates were compared with reservoir sedimentation data and with estimates obtained by using different conceptual and empirical erosion models. The resulting differences were always lower than 10\% (Ceci et al., 1998).

\section{Application to the Calvano watershed}

The regression Eqs. (1) and (2) have been herein applied to estimate the SSY for a series of subsequent river cross sections of the Calvano watershed. Given that detailed information required to apply a physically based model are not available, the geomorphic approach appears to be a valuable opportunity for the sake of identifying the river reaches that are prone to sediment deposition. In fact, geomorphic parameters can be estimated from maps or remote sensing observations and can be downscaled to the desired spatial resolution.

As it was mentioned before, an important requirement to assure the reliability of the above equations is to verify the similarity of the study watershed with the calibration and validation basins considered by Ciccacci et al. (1987). To this aim, the Calvano watershed can be included in this family of watersheds as it falls in the same geographic and morphostructural context and shows many similarities with regards to climate and geomorphological characteristics. Furthermore, it is important to note that the Calvano watershed is located few kilometres far from the Tavo River basin, which is one of the 20 fluvial basins considered by Ciccacci et al. (1987).

From a quantitative point of view, the $\Delta_{a}$ values of the whole Calvano watershed and its subcatchments are all included in the respective range spanned by the calibration data set. The same is not true for the $D_{d}$ values. In order to allow an extensive application, Eqs. (1) and (2) were used up to $D_{d}<7 \mathrm{~km}^{-1}$, therefore allowing a $25 \%$ upper extrapolation (see Table 1 ). In one case only a value $D_{d}=7.51 \mathrm{~km}^{-1}$ was considered. The SSY estimates obtained for the subcatchments where Eqs. (1) and (2) were extrapolated will be individually discussed when analysing the results.

Finally, a remark needs to be made about the watershed extension. In fact, the Calvano watershed is not included in the range of watershed size covered by the calibration data set. The extrapolation to small watershed sizes is much more significant for the case of the Calvano subcatchments considered here (see Sect. 4.2). Figure 3 shows that the performances of Eqs. (1) and (2) are not significantly related to the watershed size, which varies in the range $43-2015 \mathrm{~km}^{2}$ for the watersheds tested with the jack-knife validation. Therefore we assume here that Eqs. (1) and (2) are still valid for predicting the SSY in river cross sections with a small contributing area (a few hectares). We are fully aware that this assumption may imply the presence of further uncertainty in the SSY evaluation, that could be reduced only by including in the calibration sample a number of additional small basins. Therefore further research is needed to effectively support a technical application of the proposed approach to small size watersheds. We included such type of application in the present study in order to provide a first contribution for addressing this concern, because the presence of hill reservoirs allows us to compare some of the derived SSY estimates with reservoir siltation data. Although the latter too are affected by uncertainty that cannot be statistically quantified, the comparison we carried out seems to confirm that the order of magnitude of the SSY estimates for the small size watersheds is consistent (see Sect. 4.3).

\subsection{Quantitative geomorphic analysis and river network ac- quisition}

The geomorphic parameters $D_{d}$ and $\Delta_{a}$ were obtained by carrying out a quantitative geomorphic analysis of river network. This methodology makes it possible to obtain an objective watershed characterisation and a quantitative comparison among different river basins (Horton, 1945; Strahler, 1957; Avena et al., 1967; Avena and Lupia Palmieri, 1969). The geomorphic parameters calculation was performed by means of the GIS tool Geomorf $2 \mathrm{k} 5$, which is the updated version of Geomorf_2k1 (De Bonis et al., 2002). Geomorf_2k5 is an extension of ESRI ArcView $®$ GIS 3.2a which adds to the user interface a set of tools for computing Strahler's stream order and other geomorphic parameters. It also contains tools for removing several geometric and topological inconsistencies in the river network layer induced by editing errors, mainly shape and connectivity errors such as pseudo nodes, overlapping arcs, under- or over-shootings, apparent connections with unsplitted arcs (Fattoruso, 2005).

The Geomorf_2k5 input data were the drainage network layer and the watershed layers. The permanent streams (blue lines) of the drainage network were mapped by using the 1:25000 official topographic maps of the Italian Military Geographic Institute (IGMI). Additional information derived from the Regione Abruzzo maps with spatial scale of representation 1:10000-1:25000, aerial photographs and field observations were used to validate the blue lines. Moreover, a series of field surveys were carried out to check the consistency of the obtained blue lines with the current situation along the basin.

Watersheds limits were automatically extracted by means of the BASIN1 extension of the ArcView ${ }^{\circledR G I S}$ from a high resolution (20m) DEM obtained by vectorial elevation coverages (contour lines and single elevation points). The reliability of the GIS-derived limits was tested by comparison with the official topographic maps. The level of detail of the topographic information is the same as the previous study by Ciccacci et al. (1987). 

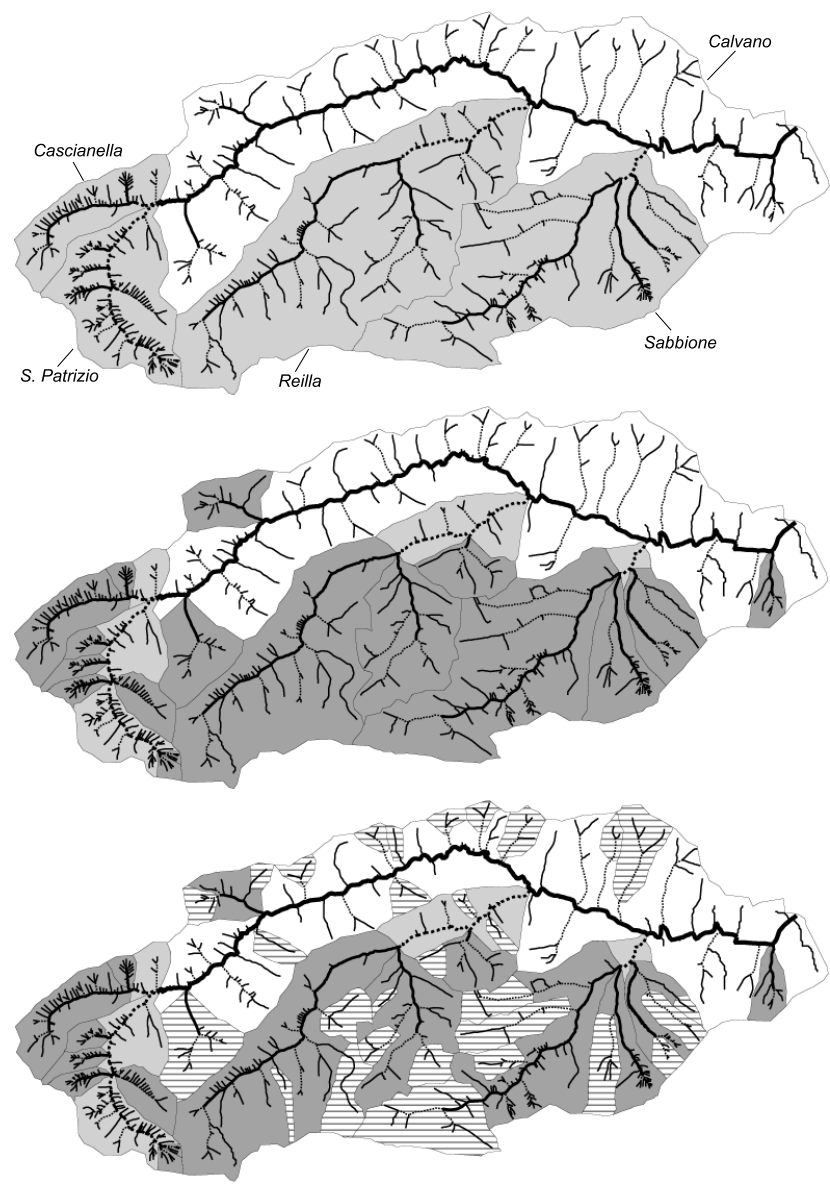

Strahler's stream orders:

(c)

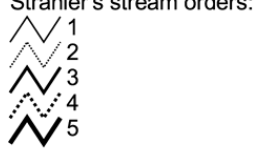

Fig. 4. Different patterns of the Calvano watershed subdivision: (a) 4th order partial catchments draining into the main stream; (b) previous plus 3 rd order sub-catchments; (c) previous plus 2 nd and 1st order secondary catchments draining into hill-reservoirs.

\subsection{Basin subdivision}

In order to evaluate the spatial distribution of soil erosion and sediment yield potential at different river sections, different subdivisions in minor order tributary basins were adopted (Fig. 4). The first subdivision groups the 4th order subcatchments (Table 2), to evaluate the gross sediment supply to the Calvano main stream. 4 subcatchments are identified (Cascianella, S. Patrizio, Reilla and Sabbione). The remaining main stream valley (5th order) is also treated as a subcatchment to investigate its sediment supply potential.

The second subdivision is extended to the 3rd order subcatchments. 17 subcatchments can be recognised, within the main stream and the 44 th order subcatchments (Table 3 ). Another subdivision was performed by identifying the 1st

(a)

(b) and 2nd order subcatchments which flow into small hill reservoirs (Table 4), in order to evaluate the contribution to reservoir siltation.

A further subdivision was made in order to identify the 1st and 2 nd order subcatchments affected by badlands (Fig. 5 and Table 5), with the aim to assess the relative significance of such severe erosion forms on the whole basin sediment balance.

\subsection{Test catchments}

Four test catchments were selected in order to verify the SSY estimates reliability on the basis of reservoir siltation data. These latter were obtained by means of bathymetric surveys and dredging operations that were carried out by the local administration and the owners. The information available about data collection do not allow derivation of an uncertainty envelope for the reservoir siltation estimates. This is a frequent situation when dealing with such kind of information. However, we believe that these data may provide a further confirmation of the consistency of Eqs. (1) and (2) for small size watersheds.

Two test reservoirs are located within the Calvano River watershed. The first, named 20-Pineto, was built in 1959 and is located in the higher part of the Sabbione subcatchment. Its drainage area is $0.77 \mathrm{~km}^{2}$. The reservoir storage was assessed trough bathymetric surveys carried out by the local administration in 1974, when it was estimated to have a residual storage capacity of $30000 \mathrm{~m}^{3}$ instead of the initial $35000 \mathrm{~m}^{3}$ in 1959 . Therefore, an average yearly sedimentation rate of about $333 \mathrm{~m}^{3}$ can be inferred, corresponding to a specific sediment supply of $4.3 \mathrm{~m}^{3} \mathrm{ha}^{-1}$ year $^{-1}$.

The second test reservoir, named 119-Atri, is located at the outlet of a 3rd order main stream tributary with a drainage area of $0.98 \mathrm{~km}^{2}$. It was built in 1970 with an initial storage capacity of $70000 \mathrm{~m}^{3}$. After 35 years, a sediment volume of about $12500 \mathrm{~m}^{3}$ was estimated after a dredging operation, corresponding to a sedimentation rate of $357.14 \mathrm{~m}^{3}$ year $^{-1}$.

The other two test reservoirs, 147-Atri and 141-Atri, are located within two stream basins (Piomba and Cerrano streams) that are located very close to the Calvano watershed and are characterised by very similar geomorphological behaviours. Both reservoirs have a contributing area of $0.15 \mathrm{~km}^{2}$. Sedimentation data were derived from dredging volumes. For the first reservoir, a sediment volume of $15000 \mathrm{~m}^{3}$ was removed after 25 years, corresponding to a sedimentation rate of $600 \mathrm{~m}^{3}$ year $^{-1}$. For the second reservoir, a volume of $1600 \mathrm{~m}^{3}$ was dredged after 22 years, corresponding to a sedimentation rate of about $70 \mathrm{~m}^{3}$ year $^{-1}$.

\subsection{Results and discussion}

Tables 2 to 5 show the sediment yield estimates by means of the Eqs. (1) and (2). For each catchment, the estimated yearly area specific sediment yield SSY $\left(\mathrm{Mg} \mathrm{km}^{-2}\right.$ year $\left.^{-1}\right)$ 
S. Grauso et al.: Estimating sediment yield by means of geomorphic parameters

Table 2. Sediment yield estimates in 4th order subcatchments and the whole Calvano River basin.

\begin{tabular}{|c|c|c|c|c|c|c|c|}
\hline Partial catchments & Area & Order & $D_{d}$ & $\Delta_{a}$ & $\log \mathrm{SSY}$ & SSY & total SY \\
\hline & $\mathrm{km}^{2}$ & & $\mathrm{~km}^{-1}$ & & & MG km ${ }^{-2}$ year $^{-1}$ & MG year ${ }^{-1}$ \\
\hline Cascianella & 1.48 & 4 & 6.5 & 0.8 & 3.6 & 4262 & 6308 \\
\hline S. Patrizio & 2.69 & 4 & 7.5 & 1.0 & 4.0 & 9905 & 26645 \\
\hline Reilla & 8.89 & 4 & 3.4 & 0.6 & 2.6 & 426 & 3785 \\
\hline \multirow[t]{2}{*}{ Sabbione } & 7.16 & 4 & 4.1 & 0.4 & 2.8 & 659 & 4718 \\
\hline & & & & & & subtotal & 41455 \\
\hline \multirow[t]{2}{*}{ Main stream partial catchment } & 14.63 & 5 & 3.5 & 1.0 & 2.7 & 481 & 7037 \\
\hline & & & & & & subtotal & 48492 \\
\hline \multirow[t]{2}{*}{ CALVANO whole basin } & 34.85 & 5 & 4.1 & 1.3 & 2.9 & 793 & 27619 \\
\hline & & & & & & SY loss from the total balance $=$ & $43 \%$ \\
\hline
\end{tabular}

Table 3. Sediment yield estimates in 3rd order subcatchments. SSY was not estimated when $D_{d}>7$.

\begin{tabular}{|c|c|c|c|c|c|c|}
\hline Subcatchment & $\begin{array}{l}\text { Area } \\
\mathrm{km}^{2}\end{array}$ & $\begin{array}{c}D_{d} \\
\mathrm{~km}^{-1}\end{array}$ & $\Delta_{a}$ & $\log \mathrm{SSY}$ & $\begin{array}{c}\text { SSY } \\
\text { MG km }^{-2} \text { year }^{-1}\end{array}$ & $\begin{array}{c}\text { total SY } \\
\text { MG year }^{-1}\end{array}$ \\
\hline \multicolumn{7}{|c|}{ CASCIANELLA } \\
\hline sub13 & 1.07 & 6.6 & 0.6 & 3.7 & 4895 & 5223 \\
\hline sub12 & 0.12 & 11.2 & 0.5 & - & - & \\
\hline \multicolumn{7}{|l|}{ S. PATRIZIO } \\
\hline sub4 & 0.17 & 7.3 & 0.2 & - & - & \\
\hline sub5 & 0.20 & 7.3 & 0.4 & - & - & \\
\hline sub6 & 0.19 & 11.3 & 0.5 & - & - & \\
\hline sub7 & 0.44 & 5.7 & 0.0 & 3.4 & 2682 & 1180 \\
\hline sub11 & 0.09 & 7.5 & 0.0 & - & - & \\
\hline sub14 & 0.03 & 24.0 & 0.0 & - & - & \\
\hline \multicolumn{7}{|l|}{ REILLA } \\
\hline Vaccareccia & 2.05 & 3.7 & 0.2 & 2.7 & 489 & 1002 \\
\hline sub8 & 0.68 & 4.3 & 0.0 & 3.0 & 933 & 635 \\
\hline sub15 & 4.92 & 3.4 & 0.5 & 2.6 & 395 & 1946 \\
\hline \multicolumn{7}{|l|}{ SABBIONE } \\
\hline sub9 & 1.05 & 4.5 & 0.0 & 3.0 & 1098 & 1153 \\
\hline sub10 & 1.15 & 4.9 & 0.4 & 3.1 & 1189 & 1368 \\
\hline sub16 & 4.77 & 3.8 & 0.4 & 2.7 & 551 & 2627 \\
\hline \multicolumn{7}{|l|}{ Main stream } \\
\hline sub1 & 0.33 & 6.1 & 0.3 & 3.5 & 3181 & 1050 \\
\hline sub2 & 0.70 & 4.0 & 0.3 & 2.8 & 612 & 428 \\
\hline \multirow[t]{2}{*}{ sub3 } & 0.98 & 2.7 & 0.1 & 2.3 & 220 & 215 \\
\hline & & & & Average & 1477 & \\
\hline
\end{tabular}


Table 4. Sediment yield estimates in secondary (mainly 1st and 2nd order) catchments draining into reservoirs.

\begin{tabular}{|c|c|c|c|c|c|c|c|}
\hline $\begin{array}{l}\text { Secondary } \\
\text { Catchments }\end{array}$ & $\begin{array}{l}\text { Area } \\
\mathrm{km}^{2}\end{array}$ & Order & $\begin{array}{c}D_{d} \\
\mathrm{~km}^{-1}\end{array}$ & $\Delta_{a}$ & $\log \mathrm{SSY}$ & $\begin{array}{c}\text { SSY } \\
\text { MG km }^{-2} \text { year }^{-1}\end{array}$ & $\begin{array}{c}\text { total SY } \\
\text { MG year }^{-1}\end{array}$ \\
\hline \multicolumn{8}{|l|}{ REILLA } \\
\hline res16 & 0.09 & 1 & 3.5 & 0.0 & 2.7 & 486 & 44 \\
\hline res17 & 0.12 & 1 & 3.2 & 0.0 & 2.6 & 397 & 48 \\
\hline res18 & 0.05 & 1 & 6.6 & 0.0 & 3.8 & 5738 & 287 \\
\hline res19 & 0.17 & 2 & 5.0 & 0.0 & 3.2 & 1619 & 275 \\
\hline res20 & 0.32 & 2 & 3.2 & 0.0 & 2.6 & 391 & 125 \\
\hline res21 & 0.47 & 1 & 2.2 & 0.0 & 2.3 & 180 & 85 \\
\hline res 25 & 0.12 & 1 & 3.0 & 0.0 & 2.5 & 351 & 42 \\
\hline res 27 & 0.07 & 2 & 6.4 & 0.0 & 3.7 & 4800 & 336 \\
\hline \multirow[t]{2}{*}{ res 28} & 0.26 & 2 & 1.9 & 0.0 & 2.2 & 146 & 38 \\
\hline & & & & & & subtotal & 1279 \\
\hline \multicolumn{8}{|l|}{ SABBIONE } \\
\hline res10 & 0.08 & 1 & 4.0 & 0.0 & 2.9 & 734 & 55 \\
\hline res11 & 0.29 & 2 & 4.1 & 0.0 & 2.9 & 775 & 211 \\
\hline res12 & 0.36 & 2 & 3.6 & 0.0 & 2.7 & 551 & 183 \\
\hline res13 & 0.59 & 2 & 3.4 & 0.0 & 2.7 & 453 & 245 \\
\hline res 15 & 0.77 & 3 & 3.6 & 0.4 & 2.5 & 478 & 368 \\
\hline res22 & 0.21 & 2 & 4.1 & 0.0 & 2.9 & 812 & 161 \\
\hline res 23 & 0.48 & 2 & 3.3 & 0.0 & 2.6 & 436 & 192 \\
\hline \multirow[t]{2}{*}{ res 24} & 0.15 & 2 & 3.6 & 0.0 & 2.7 & 555 & 77 \\
\hline & & & & & & subtotal & 1492 \\
\hline \multicolumn{8}{|l|}{ MAIN STREAM } \\
\hline res9 (sub3) & 0.98 & 3 & 2.7 & 0.1 & 2.3 & 220 & 215 \\
\hline res1 & 0.59 & 2 & 3.1 & 0.0 & 2.6 & 379 & 224 \\
\hline res2 & 0.28 & 2 & 3.8 & 0.0 & 2.8 & 648 & 181 \\
\hline res3 & 0.12 & 2 & 5.1 & 0.0 & 3.2 & 1710 & 205 \\
\hline res4 & 0.11 & 2 & 4.8 & 0.0 & 3.1 & 1334 & 147 \\
\hline res5 & 0.13 & 2 & 4.6 & 0.0 & 3.1 & 1215 & 158 \\
\hline res6 & 0.09 & 1 & 4.1 & 0.0 & 2.9 & 781 & 70 \\
\hline res8 & 0.18 & 2 & 3.7 & 0.0 & 2.8 & 590 & 106 \\
\hline res14 & 0.17 & 2 & 4.2 & 0.0 & 2.9 & 837 & 142 \\
\hline res26 & 0.13 & 2 & 4.3 & 0.0 & 3.0 & 963 & 125 \\
\hline res30 & 0.11 & 2 & 4.9 & 0.0 & 3.2 & 1452 & 160 \\
\hline res7 & 0.20 & 1 & 3.2 & 0.0 & 2.6 & 394 & 79 \\
\hline \multirow[t]{2}{*}{ res 29} & 0.09 & 1 & 5.1 & 0.0 & 3.2 & 1736 & 156 \\
\hline & & & & & & subtotal & 1969 \\
\hline $\begin{array}{l}\text { total area drained } \\
\text { by reservoirs }\end{array}$ & 8.32 & & & & & $\begin{array}{l}\text { TOTAL SY to reservoirs } \\
\text { SY \% trapped in reservoirs }\end{array}$ & $\begin{array}{l}4741 \\
17 \%\end{array}$ \\
\hline
\end{tabular}

and yearly total sediment yield SY $\left(\mathrm{Mg} \mathrm{year}^{-1}\right)$ are reported. The specific sediment yield of the Calvano River was evaluated in $792.5 \mathrm{Mg} \mathrm{km}^{-2}$ year $^{-1}$, which is very close to the average observed SSY in river basins of central Italy (Abruzzo, Marche) flowing to the Adriatic Sea (see Lupia Palmieri, 1983).
The first level of basin subdivision (4th order) shows that the $\mathrm{S}$. Patrizio stream can provide the highest sediment supply within the whole basin (about $27000 \mathrm{Mg}$ year $^{-1}$ ), followed by the Cascianella stream (about $6000 \mathrm{Mg}$ year $^{-1}$ ). Moreover, considering that these two streams join together thus originating the 5 th order main stream, it can be 
Table 5. Sediment yield estimates from catchments with badlands (calanchi). SSY was not estimated when $D_{d}>7$.

\begin{tabular}{|c|c|c|c|c|c|c|c|}
\hline $\begin{array}{l}\text { Catchments } \\
\text { with badlands }\end{array}$ & $\begin{array}{l}\text { Area } \\
\mathrm{km}^{2}\end{array}$ & Order & $\begin{array}{c}D_{d} \\
\mathrm{~km}^{-1}\end{array}$ & $\Delta_{a}$ & $\log \mathrm{SSY}$ & $\begin{array}{c}\text { SSY } \\
\text { MG km }^{-2} \text { year }^{-1}\end{array}$ & $\begin{array}{c}\text { total SY } \\
\text { MG year }^{-1}\end{array}$ \\
\hline \multicolumn{8}{|l|}{ CASCIANELLA } \\
\hline \multirow{2}{*}{$\begin{array}{l}\text { Cascianella_calanchi } \\
\text { sub12 }\end{array}$} & 1.36 & 4 & 6.0 & 0.6 & 3.5 & 2966 & 4033 \\
\hline & 0.12 & 3 & 11.2 & 0.5 & - & - & - \\
\hline \multicolumn{8}{|l|}{ S. PATRIZIO } \\
\hline \multirow{6}{*}{$\begin{array}{l}\text { S. Patrizio_calanchi } \\
\text { sub4 } \\
\text { sub5 } \\
\text { sub6 } \\
\text { sub7 } \\
\text { sub11 }\end{array}$} & 1.60 & 4 & 7.6 & 1.7 & - & - & - \\
\hline & 0.17 & 3 & 7.3 & 0.2 & - & - & - \\
\hline & 0.20 & 3 & 7.3 & 0.4 & - & - & - \\
\hline & 0.19 & 3 & 11.3 & 0.5 & - & - & - \\
\hline & 0.44 & 3 & 5.7 & 0.0 & 3.4 & 2675 & 1177 \\
\hline & 0.09 & 3 & 7.5 & 0.0 & - & 5067 & 456 \\
\hline \multicolumn{8}{|l|}{ REILLA } \\
\hline Reilla_calanchi & 3.63 & 3 & 3.7 & 0.6 & 2.7 & 495 & 1797 \\
\hline \multicolumn{8}{|l|}{ SABBIONE } \\
\hline \multirow{3}{*}{$\begin{array}{l}\text { Sabbione_calanchi } \\
\text { sub9_calanchi } \\
\text { sub10_calanchi }\end{array}$} & 2.89 & 3 & 4.2 & 0.5 & 2.9 & 711 & 2054 \\
\hline & 0.48 & 3 & 4.7 & 0.0 & 3.1 & 1186 & 570 \\
\hline & 0.50 & 3 & 6.6 & 0.5 & 3.7 & 4569 & 2284 \\
\hline \multicolumn{8}{|l|}{ MAIN stream } \\
\hline \multirow{2}{*}{$\begin{array}{l}\text { Main_calanchi } \\
\text { sub3 (res 9) }\end{array}$} & 1.99 & 3 & 4.7 & 0.3 & 3.0 & 1025 & 2039 \\
\hline & 0.98 & 3 & 2.7 & 0.1 & 2.3 & 220 & 215 \\
\hline
\end{tabular}

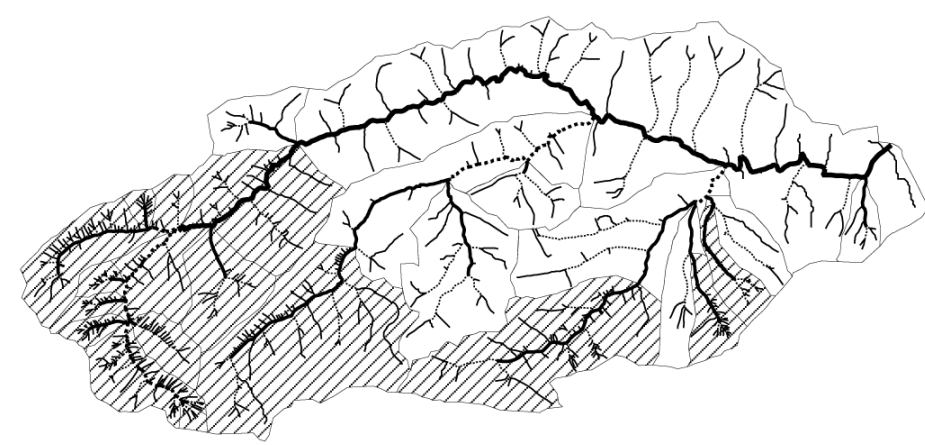

Badlands occurrence:

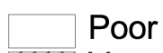

QI/l) Very high

Fig. 5. Location of catchments affected by badlands.

concluded that the river reach downstream their confluence is potentially critical in terms of sediment deposition. Analogous situations would be identified if one evaluated the results obtained at the second subdivision level (3rd order subcatchments). One should note that the $D_{d}$ values of the Cascianella and S. Patrizio watersheds are slightly outside the range spanned by the calibration data set. In particular, the $\mathrm{S}$. Patrizio basin is the only exception where we applied the method for $D_{d}>7 \mathrm{~km}^{-1}$. Therefore the uncertainty of the corresponding SSY estimates could be more significant with respect to what was inferred in Sect. 3.2.
It can be remarked that the sediment supply referred to the whole basin is lower than the sum of its subcatchment sediment yields. This is mainly explained by the different entity of drainage density. For example, when one refers to the entire Calvano basin $\left(D_{d}=4.05 \mathrm{~km}^{-1}\right)$, drainage density is lower than the average $D_{d}$ of its subcatchment (average $D_{d}=4.99 \mathrm{~km}^{-1}$ ). This produces a sediment loss quantifiable in $43 \%$ of the expected balance given by the sum of the four subcatchments plus the main valley's subcatchment sediment supply (Table 2). This indicates a potential for significant deposition along the main stream. 
Table 6. Test-reservoirs sedimentation estimates and comparison with predicted SSYs by model equations. The dry sediment bulk density was allowed to vary in the $1.2-1.5 \mathrm{Mg} \mathrm{m}^{-3}$ range.

\begin{tabular}{|c|c|c|c|c|c|c|c|c|c|c|}
\hline Reservoir & Date & $\begin{array}{l}\text { Time interval } \\
\text { years }\end{array}$ & Basin & $\begin{array}{l}\text { basin area } \\
\mathrm{km}^{2}\end{array}$ & $\begin{array}{l}D_{d} \\
\mathrm{~km}^{-1}\end{array}$ & $\begin{array}{l}\text { Estimated sediment } \\
\text { volume } \\
\mathrm{m}^{3}\end{array}$ & $\begin{array}{l}\text { Sediment dry } \\
\text { bulk density } \\
\mathrm{Mg} \mathrm{m}^{-3}\end{array}$ & $\begin{array}{l}\text { Estimated SSY } \\
\mathrm{Mg} \mathrm{km}^{-2} \text { year }^{-1}\end{array}$ & $\begin{array}{l}\text { Predicted SSY } \\
\mathrm{Mg} \mathrm{km}^{-2} \text { year }^{-1}\end{array}$ & Difference \\
\hline 20 Pineto & 1959 & 15 & Sabbione & 0.77 & 3.65 & 5000 & $1.2-1.5$ & 519-649 & 478 & $8 \%-26 \%$ \\
\hline 119 Atri & 1970 & 35 & Calvano & 0.98 & 2.71 & 12500 & $1.2-1.5$ & $437-547$ & 220 & $50 \%-60 \%$ \\
\hline 147 Atri & 1963 & 25 & Piomba & 0.15 & 5.98 & 15000 & $1.2-1.5$ & $4800-6000$ & 3465 & $28 \%-42 \%$ \\
\hline \multirow[t]{2}{*}{141 Atri } & 1971 & 22 & Cerrano & 0.15 & 4.28 & 1600 & $1.2-1.5$ & $582-727$ & 926 & $27 \%-59 \%$ \\
\hline & & & & & & & & & average difference & $38 \%$ \\
\hline
\end{tabular}

If one considered the 3rd order subcatchments of the Calvano River (Table 3), a mean SSY value of $1477 \mathrm{Mg} \mathrm{km}^{-2}$ year $^{-1}$ would be estimated, but this value is affected by the exclusion of the basins with $D_{d}>7 \mathrm{~km}^{-1}$ that will likely contribute with much higher SSY values.

Table 4 reports the SSY estimates referred to river section located immediately upstream 30 small hill reservoirs located in the Calvano watershed. The overall area drained by reservoirs $\left(8.32 \mathrm{~km}^{2}\right)$ is about $24 \%$ of the whole Calvano basin. It turns out that $4741 \mathrm{Mg} \mathrm{year}^{-1}$ of sediments are entering into reservoirs. If one assumes that these sediments are completely trapped into the reservoirs, which is reasonable under appropriate working conditions, it appears that $17 \%$ of the Calvano yearly sediment yield might be trapped. This means that hill reservoirs are potentially effective in order to limit the siltation of the downstream river network.

Table 5 reports the SSY estimates obtained for the subcatchments where the badlands (calanchi) are located. SSY was estimated only for those watersheds where $D_{d}<7 \mathrm{~km}^{-1}$. Badlands affect the whole area of Cascianella and S. Patrizio and a large portion of Reilla and Sabbione subcatchments. The total surface affected by badlands amounts to $14.64 \mathrm{~km}^{2}$, corresponding to $42 \%$ of the whole Calvano area. In general, the drainage density for all the badlands is significantly high, therefore implying that these areas are particularly prone to soil erosion. In fact, if one only considers the basins where $D_{d}<7 \mathrm{~km}^{-1}$, their area is $35 \%$ of whole Calvano area, while their SY is $44 \%$ of the total basin SY. By considering that the badlands with the higher drainage density $\left(D_{d}>7 \mathrm{~km}^{-1}\right)$, and therefore the higher soil erosion potential, were excluded by this analysis, one can conclude that a significant part of the sediment supply to the Calvano main stream is produced by badlands. This is consistent with what is usually observed in environments with similar geomorphological behaviours.

SSY estimates were also computed for the small catchments draining into the selected test reservoirs. The comparison between the sediment volumes trapped by the reservoirs, converted into sediment yield, and the predicted SSY data allowed us to test the reliability of the SSY estimates for those small size basins (Table 6). The reservoir sediment volume data are to be converted into dry weight units and corresponding specific sediment yield by estimating the dry bulk density of the sediments themselves. In absence of direct geotechnical measurements in the test reservoirs, we assumed that the dry sediment bulk density varies in the range $1.2-1.5 \mathrm{Mg} \mathrm{m}^{-3}$. This value was inferred on the basis of direct measurements of humid sediment bulk densities ranging from 1.6 to $1.9 \mathrm{Mg} \mathrm{m}^{-3}$ that were collected in the Penne reservoir, located along the Tavo River (Ceci et al., 1998), which is similar to the Calvano River from a climatic and geomorphological point of view (the two watersheds are quite close each other, see Sect. 3.3 and Sect. 4). According to literature indications, the above ranges and their interrelation are reasonable for low compaction sandy-clay materials.

Table 6 shows the range of the predicted SSY into the reservoirs, obtained by allowing the dry bulk density of the sediments to vary within the above range. It can be seen that in the four examined cases the predicted SSY show an average difference of $38 \%$ if they are compared with reservoir sedimentation data, the best result being showed by 20 Pineto reservoir, where the difference between observed and predicted SSY is in the range 8\%-26\%. Reservoirs 119-Atri and 141-Atri show a more significant difference. Overall, it can be seen that the comparison provides consistent results. Even if the uncertainty that affects the sediment bulk density and the estimated SSY does not allow one to draw a final conclusion, the order of magnitude of the predicted values is consistent with what was estimated in the field. This result provides a first support to the assumption that the proposed method is valid for predicting the SSY in river sections with small contributing area (down to a few hectares).

A last consideration concerns the relations between sediment yield and basin exposure. In fact, if one grouped the examined secondary (mainly 1 st and 2 nd order) catchments into prevalently southward and prevalently northward facing (Table 7), one could see that the mean drainage density in the southward facing group is about $4.6 \mathrm{~km}^{-1}$, against a mean value of $3.1 \mathrm{~km}^{-1}$ for the northward facing group. The reason for this outcome is that in south facing catchments the vegetal coverage is more discontinuous, given the lower soil humidity, and then sediment erosion processes and channels network development are favoured. Accordingly, Table 7 shows 
Table 7. Sediment yield comparison between south- and northward facing catchments.

\begin{tabular}{|c|c|c|c|c|c|c|c|}
\hline Catchment & $\begin{array}{l}\text { Area } \\
\mathrm{km}^{2}\end{array}$ & Order & $\begin{array}{c}D_{d} \\
\mathrm{~km}^{-1}\end{array}$ & $\Delta_{a}$ & $\log \mathrm{SSY}$ & $\begin{array}{c}\text { SSY } \\
\text { MG km }^{-2} \text { year }^{-1}\end{array}$ & $\begin{array}{c}\text { total SY } \\
\text { MG year }^{-1}\end{array}$ \\
\hline \multicolumn{8}{|c|}{ southward catchments } \\
\hline (main) sub2 & 0.43 & 3 & 4.0 & 0.3 & 2.8 & 626 & 269 \\
\hline res 1 & 0.59 & 2 & 3.1 & 0.0 & 2.6 & 379 & 224 \\
\hline res2 & 0.28 & 2 & 3.8 & 0.0 & 2.8 & 648 & 181 \\
\hline res3 & 0.12 & 2 & 5.1 & 0.0 & 3.2 & 1710 & 205 \\
\hline res4 & 0.11 & 2 & 4.8 & 0.0 & 3.1 & 1334 & 147 \\
\hline res5 & 0.13 & 2 & 4.6 & 0.0 & 3.1 & 1215 & 158 \\
\hline res26 & 0.13 & 2 & 4.3 & 0.0 & 3.0 & 963 & 125 \\
\hline res30 & 0.11 & 2 & 4.9 & 0.0 & 3.2 & 1452 & 160 \\
\hline res29 & 0.09 & 1 & 5.1 & 0.0 & 3.2 & 1736 & 156 \\
\hline \multirow[t]{2}{*}{ (reilla)res27 } & 0.07 & 2 & 6.4 & 0.0 & 3.7 & 4800 & 336 \\
\hline & & & & & average & 1486 & 196 \\
\hline \multicolumn{8}{|c|}{ northward catchments } \\
\hline (main) (res9) sub3 & 0.98 & 3 & 2.7 & 0.1 & 2.3 & 220 & 215 \\
\hline res8 & 0.18 & 2 & 3.7 & 0.0 & 2.8 & 590 & 106 \\
\hline res7 & 0.20 & 1 & 3.2 & 0.0 & 2.6 & 394 & 79 \\
\hline (reilla) res16 & 0.09 & 1 & 3.5 & 0.0 & 2.7 & 486 & 44 \\
\hline res 21 & 0.47 & 1 & 2.2 & 0.0 & 2.3 & 180 & 85 \\
\hline res20 & 0.32 & 2 & 3.2 & 0.0 & 2.6 & 391 & 125 \\
\hline res 28 & 0.26 & 2 & 1.9 & 0.0 & 2.2 & 146 & 38 \\
\hline (sabbione) res 10 & 0.08 & 1 & 4.0 & 0.0 & 2.9 & 734 & 59 \\
\hline \multirow[t]{2}{*}{ res 23} & 0.48 & 2 & 3.3 & 0.0 & 2.6 & 436 & 209 \\
\hline & & & & & average & 398 & 107 \\
\hline
\end{tabular}

that the estimated SSY from southward catchments resulted, on average, well higher than that from northward catchments.

\section{Conclusions}

This study considers the potential application of multiple regression relationships to estimate potential river sediment yield, depending on geomorphic parameters of the contributing area. This kind of approach is potentially useful in order to obtain technical indications about sediment sources in a watershed in absence of the more detailed information that are needed in order to apply a physically based approach. Given that any empirical model, like the method considered here, is calibrated by referring to specific contexts and is potentially subjected to uncertainty in out of sample applications, a jack-knife validation has been performed in order to test the performances of the suggested technique. Moreover, a further validation of the obtained sediment yield estimates has been performed by using reservoir siltation data.

By using simple regression relationships, such as those adopted here, it is possible to recognise the river cross sections along the main stream which are more critical in terms of sediment yield and therefore the river streams were sed- iment deposition is likely to occur. We believe this kind of approach might be a valuable opportunity for assessing the soil erosion potential over a watershed and stream siltation along a river network. However, the analysis herein carried out refers to a relatively limited range of drainage density and hierarchical anomaly index. Therefore, the analysis of additional field data of suspended sediment yield is needed in order to widen the possible context of application of the proposed method. In particular, we believe additional research is needed to further test the reliability of the SSY estimates for small size watersheds.

Finally, one should note that the topological behaviours of the river network can be meaningfully related to the suspended sediment yield provided the soil erosion is significantly correlated with the river discharge. This requirement is not satisfied in the presence of local and massive sediment inputs to the river network, like those provided by landslides. This is an important consideration for practical applications.

Acknowledgements. The authors are sincerely grateful to S. Uhlenbrook, Editor of this paper, P. D'Odorico and three anonymous referees for providing useful suggestions. The work presented here has been carried out in the framework of the activity of the Working Group at the University of Bologna of the Prediction in 
Ungauged Basins (PUB) initiative of the International Association of Hydrological Sciences. The study has been partially supported by the Italian Government through its national grant to the program on "Advanced techniques for estimating the magnitude and forecasting extreme hydrological events, with uncertainty analysis".

Edited by: S. Uhlenbrook

\section{References}

Agnesi, V., Del Monte, M., Fredi, P., Macaluso, T., and Messana, V.: Contributo dell'analisi geomorfica quantitativa alla valutazione dell'erosione del suolo nel bacino del fiume Imera settentrionale (Sicilia centro-settentrionale). Proceedings of the Workshop "Erosione del Suolo, Gestione dei Sedimenti e Morfologia delle Coste", Palermo, Italy, 101-115, 1996.

Anderson, H. W.: Relating Sediment Yield to Watershed Variables, Transactions, American Geophysical Union, 38(6), 921924, 1957.

Avena, G. C. and Lupia Palmieri, E.: Analisi geomorfica quantitativa, in: Idrogeologia dell'alto bacino del Liri, edited by: Accordi, B., Geologica Romana, VIII, Università degli Studi di Roma, 319-378, 1969.

Avena, G. C., Giuliano, G., and Lupia Palmieri, E.: Sulla valutazione quantitativa della gerarchizzazione ed evoluzione dei reticoli fluviali, Boll. Soc. Geol. It. 86, 781-796, 1967.

Battista, C., Boenzi, F., and Pennetta, L.: Una valutazione dell'erosione nel bacino idrografico del torrente Arcidiaconata in Basilicata, Suppl. Geogr. Fis. Dinam. Quat., 1, 235-246, 1988.

Cannarozzo, M. and Ferro, V.: Un semplice modello regionale per la valutazione del trasporto solido in sospensione nei corsi d'acqua siciliani, Atti Acc. Scienze Lettere e Arti di Palermo serie, V 5, 95-137, 1985.

Cannarozzo, M. and Ferro, V.: Confronto tra alcuni modelli per la previsione del volume di interrimento dei serbatoi artificiali siciliani. Atti Acc. Scienze Lettere e Arti di Palermo serie, V 8, 103-119, 1988.

Cavazza, S.: Contributo al calcolo del potenziale di erosione, Riv. It. Geof., 21, 27-32, 1972.

Cavazza, S.: Sulla erodibilità dei terreni di alcuni bacini calabro lucani, in: Aspetti geografici dell'erosione del suolo in Italia, edited by: G. Morandini, CNR Padova, 177-196, 1962.

Ceci, D. P., Farroni, A., and Magaldi, D.: Applicazione del codice di calcolo Raizal per la valutazione del rischio di erosione nel bacino del fiume Tavo, Geoingegneria Ambientale e Mineraria, Politecnico di Torino, 285-291, 1998.

Ciccacci, S., Fredi, P., and Lupia Palmieri, E.: Rapporti fra trasporto solido e parametri climatici e geomorfici in alcuni bacini idrografici italiani. Workshop "Misura del trasporto solido al fondo nei corsi d'acqua", Consiglio Nazionale delle Ricerche, Florence, Italy, 1977.

Ciccacci, S., Fredi, P., Lupia Palmieri, E., and Pugliese, F.: Contributo dell'analisi geomorfica quantitativa alla valutazione dell'entità dell'erosione nei bacini fluviali, Boll. Soc. Geol. It., 99, 455-516, 1980.

Ciccacci, S., Fredi, P., Lupia Palmieri, E., and Pugliese, F.: Indirect evaluation of erosion entity in drainage basins through geomorphic, climatic and hydrological parameters, in: International Ge- omorphology 1986 Part II, edited by: Gardiner, V., John Wiley and Sons Ltd, Chichester, 33-48, 1987.

Ciccacci, S., D'Alessandro, L., Fredi, P., and Lupia Palmieri, E.: Contributo dell'analisi geomorfica quantitativa allo studio dei processi di denudazione nel bacino idrografico del torrente Paglia, Suppl. Geogr. Fis. Dinam. Quat., 1, 171-188, 1988.

CNR-GNDCI: Progetto AVI - Relazione Regione Abruzzo, U.O. No. 10, Società di Geologia Applicata, 1993.

Commissione Tecnica: "Progetto di massima e preliminare dei lavori per l'eliminazione delle problematiche esistenti ed emerse a seguito degli aventi alluvionali del 9 e 10 luglio 1999”, Technical Report, Comune di Pineto, 1999.

De Bonis, P., Fattoruso, G., Grauso, S., Peloso, A., and Regina, P.: Computation of geomorphic parameters via GIS-based algorithms: a support tool in river systems management, Proc. Second International Conference "New Trends in Water and Environmental Engineering for Safety and Life: Eco-Compatible Solutions for Aquatic Environments", Capri, Italy, 136-137, 2002.

Douglas, I.: Sediment sources and causes in the humid tropics of northeast Queensland, Australia, in: Geomorphology in a Tropical Environment, edited by: Harvey, A. M., Brit. Geom. Res. Group. Occ. Pap., 5, 27-39, 1968.

Fattoruso, G.: Hydrography and GIS's - Removing Inconsistencies in Vector River Networks Extracted from Cartography, GeoInformatics, 8, 48-49, 2005.

Fournier, F.: Climat et érosion: la relation entre l'érosion du sol par l'eau et les précipitations atmosphériques, Presses Univ. de France, Paris, 1960

Gazzolo, T. and Bassi, G.: Relazione tra i fattori del processo di ablazione ed il trasporto solido in sospensione nei corsi d'acqua italiani, Min. lav. Pubbl., Giornale del Genio Civile, 6, 377-395, 1964.

Gazzolo, T. and Bassi, G.: Contributo allo studio del grado di erodibilità dei terreni costituenti i bacini montani dei corsi d'acqua italiani, Min. lav. Pubbl., Giornale del Genio Civile, 1, 9-19, 1961.

Grauso, S., De Bonis, P., Fattoruso, G., Onori, F., Pagano, A., Regina, P., and Tebano, C. : Relations between climaticgeomorphological parameters and suspended sediment yield in a Mediterranean semi-arid area (Sicily, southern Italy), Environ. Geol., doi:10.1007/s00254-007-0809-4, 2007.

Haan, C. T.: Statistical methods in hydrology, Iowa State University Press, 1977.

Horton, R. E.: Erosional development of streams and their drainage basins; hydrophysical approach to quantitative morphology, Bull. Geol. Soc. Amer. 56, 275-370, 1945.

Ichim, I. and Radoane M.: A multivariate statistical analysis of sediment yield and prediction in Romania, in: Geomorphological Models: Theoretical and Empirical Aspects, edited by: Ahnert, F., Catena Supplement, 10, 137-146, 1987.

Kirkby, M. J. and Cox, N. J.: A climatic index for soil erosion potential (CSEP) including seasonal and vegetation factors, Catena, 25, 333-352, 1995.

Kottegoda, N. T. and Rosso, R.: Probability, Statistics, and Reliability for Civil and Environmental Engineers, McGraw-Hill, New York, 1997.

Langbein, W. B. and Schumm, S. A.: Yield of sediment in relation to mean annual precipitation, Transactions, American Geophysical Union, 39(6), 1076-1084, 1958. 
Lorè A. and Magaldi D.: Valutazione del rischio di erosione del suolo: un esempio in Provincia dell'Aquila, CNR Quaderni di Scienza del Suolo, 6, 5-18, 1995.

Lupia Palmieri, E., Ciccacci, S., Civitelli, G., Corda, L., D’Alessandro, L., Del Monte, M., Fredi, P., and Pugliese, F.: Geomorfologia quantitativa e morfodinamica del territorio abruzzese: il bacino idrografico del fiume Sinello, Geogr. Fis. e Dinam. Quatern., 18(1), 31-46, 1995.

Lupia Palmieri, E.: Il problema della valutazione dell'entità dell'erosione nei bacini fluviali, Proc. XXIII Congr. Geog. It. Catania, Italy, 143-176, 1983.

Massaro, M. E., Russo, M., and Zuppetta, A.: Analisi indiretta dell'entità dell'erosione nel bacino del fiume Tammaro, Geogr. Fis. Dinam. Quatern., 19(2), 381-394, 1996.

Renard, K. G., Foster, G. R., Weesies, G. A., McCool, D. K., and Yoder, D. C.: Predicting soil erosion by water. A guide to conservation planning with the Revised Universal Soil Loss Equation (RUSLE), United States Department of Agriculture, Agricultural Research Service (USDA-ARS) Handbook No. 703, United States Government Printing Office, Washington DC, 1997.
Restrepoa, J. D., Kjerfveb, B., Hermelina, M., and Restrepoa, J. C.: Factors controlling sediment yield in a major South American drainage basin: the Magdalena River, Colombia, J. Hydrol., 316, 213-232, 2006.

Strahler, A. N.: Quantitative Analysis of Watershed Geomorphology. Transactions, American Geophysical Union, 38(6), 913920, 1957.

Wicks, J. M. and Bathurst, J. C.: SHESED: a physically based, distributed erosion and sediment yield component for the SHE hydrological modelling system, J. Hydrol., 175, 213-238, 1996.

Williams, J. R.: Sediment-yield prediction with universal equation using runoff energy factor, in: Present and prospective technology for predicting sediment yield and sources, ARS.S-40, U.S. Gov. Print. Office, Washington, 244-252, 1975.

Wischmeier, W. H. and Smith, D. D.: Predicting rainfall erosion losses from cropland east of the Rocky Mountains, United States Department of Agriculture - Handbook no. 282, United States Government Printing Office, Washington DC, 1965.

Wischmeier, W. H. and Smith, D. D.: Predicting rainfall erosion losses: a guide to conservation planning. United States Department of Agriculture, Handbook no. 537, United States Government Printing Office, Washington DC, 1978. 